УДК $316.7(06)$

\title{
СОЦИАЛЬНАЯ ИНЕРЦИЯ КАК ФАКТОР УСТОЙЧИВОСТИ ТРАДИЦИОННЫХ ГЕНДЕРНЫХ СТЕРЕОТИПОВ
}

\author{
(C) 2012 г. Ю. Г. Тищенко
}

\section{Шахтинский институт (филиал) Южно-Российского государственного технического университета (НПИ)}

В статье изложены основные результаты сочиологического анализа гендерных стереотипов студенческой молодежи Ростовской области, представлены факторы, обусловливающие их (стереотипов) устойчивость, а также приверженность современного студенчества традиционной культуре.

Ключевые слова: гендерные стереотипь; социальная инерияи; динамика общественного развития.

The article presents the basic results of the sociological analysis of the students'gender stereotypes in the Rostov region, the factors that contribute to these stereotypes' stability and the commitment of nowadays students to the traditional culture.

Key words: gender stereotypes; social inertia; the dynamics of social development.

Социологическое исследование, проведенное нами среди студентов двух городов Ростовской области, Шахты и Ростова-на-Дону, отчетливо показало устойчивость традиционных гендерных стереотипов. Несколько десятилетий социально-экономических преобразований, технологические революции, изменение ценностной основы развития российского общества должны, как мы полагали, трансформировать гендерные установки молодого поколения, особенно студенчества, как самой передовой его части. Ставя задачу всестороннего исследования степени приверженности студентов гендерным стереотипам традиционной культуры, мы были уверены, что студенческая молодежь, особенно города-миллионера, будет менее стереотипизирована, чем старшее поколение и другие категории населения. Именно она должна стать проводником гендерного равенства, «современных» моделей поведения и отношений между полами.

Однако анализ результатов проведенного нами опроса студентов выявил значительную степень стереотипности их гендерного сознания. Пространственная локализация молодых людей в различных по масштабу территориальных образованиях не является существенным коррелятом, определяющим большую или меньшую степень их гендерной стереотипизации.

Устойчивость гендерных стереотипов коренится, очевидно, в культурно-историческом происхождении приписываемых членам гендерных сообществ типических черт и особенностей. Гендерные стереотипы, как и другие социальные стереотипы, являются глубоко укоренившимися представлениями, трудно изменяемыми и часто неосознаваемыми. Они являются «примером неосознанной идеологии, иначе говоря, набором убеждений, которые мы внутренне приемлем, но в которых не отдаем себе отчета, поскольку даже не мыслим себе альтернативных концепций окружающего мира» [1, с. 421]. Укоренившись в индивидуальном сознании в форме доминирующих представлений, гендерные стереотипы транслируются из поколения в поколение. Но в некоторой степени они могут изменяться под влиянием объективных условий, таких как социально-экономические или политические трансформации, но 
этот процесс очень сложен и длителен. Так, например, повсеместное вовлечение женщин в общественное производство, характерное для второй половины XX столетия, повлекло за собой изменение стереотипа, ограничивающего сферу деятельности женщины исключительно интересами семьи, но для этого потребовались десятилетия. Субъективные же факторы, связанные с индивидуальнопсихологическими особенностями личности и условиями её социализации, еще более ригидны, чем объективные.

Широкая распространенность традиционных гендерных стереотипов свидетельствует о все еще не преодоленном в российском обществе гендерном неравенстве, пронизывающим структуру и функции всех общественных институтов - от семьи до экономики и государства. Данный вид неравенства является, пожалуй, самым консервативным и устойчивым, поскольку опирается на многовековые традиции, формируя устойчивые стереотипы в обществе и ощущение, что такое распределение ролей было всегда, значит оно - априори. В гендерном неравенстве биологические и социальные факторы неразрывно связаны, что питает иллюзию его естественности. Оно, как правило, многослойно и плотно пересекается с неравенством по возрасту, месту проживания, национальности и др. Одного экономического роста явно недостаточно для его устранения. Установление современного, эгалитарного гендерного порядка предполагает развитие институтов гендерного равенства посредством внедрения законодательных норм и специальных институциональных организаций, отстаивающих равенство полов, введение основанных на нем (равенстве) современных общественных норм поведения и отношений.

Гендерное равенство основывается на равном доступе женщин и мужчин к экономическим ресурсам и равноценности «женских» и «мужских» профессий, ролей в обществе; равном отношении общества к вкладу тех и других в его экономическое (и демографическое) развитие. Гендерное равенство выступает важнейшим условием увеличения возможностей для всестороннего гармоничного развития индивидов, свободы выбора ими конкретных стратегий поведения во всех сферах жизнедеятельности (работа, семья, личное развитие) в течение разных стадий их жизненного цикла.

В эгалитарном гендерном порядке этот выбор осуществляется без давления со стороны общества, без принуждения следовать моделям поведения представителя конкретного пола, без жесткого разделения труда по половому признаку и т. д. Ресурсы современного, модернизированного общества, в котором гендерное равенство признается необходимым условием его поступательного движения, направлены на развитие личности каждого человека, создание условий для реализации его потребностей в рамках сформированной системы ценностей вне зависимости от половой принадлежности индивида (а также его возрастной группы, национальности и т. д.). Подобная стратегия соответствует представлениям о развитии человеческого потенциала, как основной цели общественного развития. Реальная свобода выбора может существовать только в условиях паритета между полами в обладании ресурсами. Эгалитарный гендерный порядок позволяет равномерно распределять ресурсы между полами, утверждает статусный и ролевой паритет мужчин и женщин, что дает возможность выравнивать и повышать отдачу от человеческого капитала.

Причины установленной нами стабильности традиционных гендерных стереотипов кроются, как мы полагаем, в воздействии социальной инерции. Собственно устойчивость гендерных стереотипов в массовом сознании и есть одно из проявлений социальной инерции.

В социальные науки понятие инерции пришло из естествознания, где оно используется для обозначения свойств материи сохранять устойчивое, равномерное движение в результате отсутствия или уравновешивания внешних воздействий. Полное перенесение свойств инерции, описанных на примере природных процессов, в социальную реальность было бы непростительной идеализацией, поскольку невозможно в действительности обеспечить уравновешивание различных воздействий, как и сложно представить, что на объект могут влиять только какие-либо однонаправленные или противоположные силы.

Признание инерционности в качестве неотъемлемого компонента социальных из- 
менений означает (в теоретико-методологическом аспекте) их анализ с позиций системного подхода, отождествляющего инерцию с формой самодвижения материи и устанавливающего активность и динамизм ее свойств, а отнюдь не консерватизм.

Социальная инерция - это не только сохраняющееся влияние прежних, отживших свое культурных элементов и комплексов в современном обществе, но и показатель его целостности, способности к продолжению развития. В определении, данном Н. А. Матвеевой, инерция - это «качественная характеристика социального субъекта, выражающая его связь с традиционной социальной средой и способность к сопротивлению незапланированным общественным процессам, не совпадающим с системой ценностей и формами жизнедеятельности социального субъекта» [2, с. 22]. Таким образом, инерция пересекается в смысловом поле с понятиями «традиция» и «воспроизводство», но никак не стагнация. Скорее непоследовательные и несвоевременные трансформации могут обусловливать стагнацию систем, нежели их инерционность.

Социальную инерцию не следует отождествлять только с устойчивостью; она складывается из равнодействующих сил: изменчивости и устойчивости, и предстает как стабильное сохранение определенных изменений. Иначе говоря, устойчивое существование социальной формы неразрывно связано с ее изменениями.

Инерция, как исходный момент социальных изменений, всегда неразрывно связана с социокультурными условиями конкретного общества, поэтому при анализе инерционности социальных процессов в современной России необходимо учитывать устойчивость и воспроизводство элементов и установок традиционной культуры, оказывающих сдерживающее влияние на современное - инновационное развитие общества.

Социальная инерция проявляется на разных уровнях витальности социальных систем: в повседневных поведенческих практиках субъектов, деятельности социальных институтов, ценностно-нормативной структуре общества. Отдельные люди, социальные общности, группы, социальные институты, подсистемы общества, его различные типы обладают разной скоростью инерции. Социальный субъект меняется тем медленнее, чем больше его сила инерции, которая определяется его (субъекта) накопленным социальным потенциалом.

В социальной инерции всегда присутствуют две стороны, объективная, отражающая характер развития социальных структур, социально-экономические противоречия и т. д., и субъективная, воспроизводящая свойства носителей изменений и проявляющаяся в инерции мышления, приверженности устаревшим стереотипам, моделям поведения и отношений.

Процессы инерционности на всех уровнях социальных систем - от макроструктур, общества в целом, его ценностно-нормативного и институционального основания, до микростуктур - поведения в повседневном, межличностном взаимодействии индивидов, имеют характер взаимозависимости. Инерционность на микроуровне - приверженность индивидов традиционным стереотипным установкам определяет инерционность общества в целом, и наоборот, косность, консерватизм социальных институтов оказывает сдерживающее, инерционное влияние на социальные устремления людей. Возникает закономерный вопрос: «При каких условиях социальная инерционность становится дисфункциональной, способствует не сохранению системы, а ее упадку, застою, отставанию, неизбежно ведущим к распаду общества?».

Инерционность препятствует поступательному движению общества, становится крайне консервативной силой в том случае, когда большая часть социума привержена современным ценностям, ориентирована преимущественно на инновации и не имеет потребности воспроизводить традиционную социальную среду. В этих условиях инерционность оказывает сдерживающее влияние на реформирование современного общества, нарушает баланс между традицией и модернизацией, выступая следствием консерватизма институциональных структур.

Инерционность всегда сопряжена с доминирующей системой ценностей, выступая механизмом их воспроизводства. Инерция социального поведения неизбежно основывается на инерции системы ценностей. По 
мнению Р. Фуллера и Р. Майерса «люди не хотят поддерживать программы улучшения, которые наносят ущерб значимым для них убеждениям или институтам или требуют отказа от них» [3, с. 55]. Социальные изменения не будут успешными, если новые виды практик не совпадают с имеющейся системой ценностей; если система «новых» ценностей опережает возможности человека по адаптации к ним и интериоризации; если способы внедрения инноваций в систему ценностей не совпадают с желаниями и возможностями человека их воспринимать. В ситуации диссонанса между массово-типичными социальными действиями, заданными новыми, модернизированными структурами и системой ценностей, не согласующейся с ними, социальная инерция становится преградой инновационного развития. Она приводит к нарушению устойчивости, целостности общества при условии его жесткой поляризации на сторонников инновационного развития и «традиционалистов», агрессивно отстаивающих незыблемость прежнего порядка. Антагонизм между ними грозит принять патологические формы, перерасти в открытый конфликт. Таким образом, социальная инерционность выступает качественной характеристикой социальных изменений, отражает содержание и динамику развития общества. В содержании инерционных процессов отчетливо проявляются сущностные черты эпохи и уровень социальной субъектности человека в конкретных исторических условиях.

Социологическое исследование гендерных представлений студенческой молодежи городов Ростовской области выявило значительную степень её (молодежи) гендерной стереотипизации по типу патриархальной культуры. Студенты разных типов урбанизации демонстрируют аналогичные стереотипные представления как о свойствах маскулинности, так и феминности. Испытуемые устойчиво связывают с маскулинностью инструментальные черты личности, «активнотворческие» характеристики; их женский стереотипный образ полностью соответствует традиционным патриархальным представлениям, т. е. мужчина продолжает восприниматься студентами, как и в традиционной патриархальной культуре - агрессивным, предприимчивым, доминирующим, незави- симым и т. д., а женщина - кроткой, нежной, альтруистичной, нуждающейся в покровительстве и защите [4].

Анализ гендерных стереотипов респондентов о семейных и профессиональных ролях мужчин и женщин выявил достаточно высокую степень приверженности студенческой молодежи традиционным патриархальным представлениям о главенстве мужчины в семье, его доминировании, высокостатусности в профессиональной сфере, и о второстепенности, подчиненности женщины в сфере занятости, её основном поле самореализации - семейной сфере.

Наше исследование подтвердило многочисленные выводы как отечественных, так и зарубежных исследователей о том, что мужчины как высокостатусные группы чаще всего оцениваются в терминах компетентности и экономического успеха, а женщины как низкостатусные группы - в терминах доброты, гуманности, исполнительности и т. д. Стереотип о дифференциации профессий на мужские и женские оказался для наших респондентов устойчивым и разделяемым независимо от пола опрашиваемых, что обусловлено, на наш взгляд, стереотипными представлениями студентов обоего пола образов феминности и маскулинности.

Вместе с тем, результаты проведенного нами исследования свидетельствуют также о том, что гендерным представлениям девушек, обучающихся в ростовских вузах, не свойственна полярная стереотипизация характеристик мужчин и женщин; в значительно большей степени, чем остальные испытуемые они демонстрируют приверженность инновационному конструкту в приватной и публичной сферах деятельности.

Таким образом, гендерные стереотипы современной студенческой молодежи характеризуются в целом противоречивостью, неоднородностью, что проявляется в эклектичном сочетании у субъектов стереотипизации установок, стереотипных представлений традиционной и модернистской культуры. Столь «причудливый» симбиоз гендерных установок сложился в результате взаимодействия сложносочетаемых ценностей традиционного общества и модернизационных устремлений, сформированных под воздействием западных ценностей и проводимых в послед- 
ние годы в России реформ. Взаимоисключение, несовместимость стереотипов модернистского общества и общества традиционалистского становится фактором усиления в социальной системе стохастичных процессов, обусловливающих снижение потенциала ее устойчивости и стабильности.

В современном российском обществе так и не сложились нормативные основания для единообразного понимания социальных ценностей, то есть слабо выражена (или вообще отсутствует) система общепринятых ценностей и норм. Система неформального контроля практически не функционирует, институционализация ролей по типу современного общества не завершена. В этих условиях инерционность, проявляющаяся в том числе и в устойчивости стереотипных установок традиционной культуры, заявляет о себе как о значимом факторе социальных изменений, сдерживающим общество от погружения в состояние хаоса.

Стереотипные представления традиционного общества противоречат основным тенденциям современной жизни, её модернистским ценностям. Жесткая поляризация российского социума на «традиционалистов» и «модернистов» способна нарушить параметры его устойчивости. Состояние аномии, переживаемое современным российским обществом, его экономическая нестабильность, ценностный разлад препятствуют сплочению общества вокруг модернистских ценностей, так и не ставших для большинства россиян бесспорно значимыми. Функционирование разнородных гендерных стереотипов порождает состояние неопределенности, приводящее к девальвации социальных ценностей, ценностно-нормативному вакууму, дезориентации человека в подобном социокультурном пространстве и, как следствие - невозможность его адаптации и ценностная маргинализация.

\section{Литература}

1. Аронсон Э. Общественное животное. Введение в социальную психологию. Изд. 7. / Пер. с англ. М. А. Ковальчука, под ред. В. С. Магуна. - М.: Аспект-Пресс, 1998. - С. 421. [Электронный ресурс] / Педагогическая библиотека. - Режим доступа: http://www. pedlib.ru/Books/3/0426/3_0426-421.shtml, свободный. - Загл. с экрана.

2. Матвеева Н. Социальная инерция. К определению понятия. // Социологические исследования. - 2004. - №4. - С. 22.

3. Фуллер Р., Майерс Р. История социальной проблемы. // Контексты современности 2. Хрестоматия. / Пер. с англ. / Отв. ред. А. В. Кудрявцев. - Казань, 1998. - С. 55.

4. Либин A. B. Дифференциальная психология: на пересечении европейских, российских и американских традиций. M., 1999. 


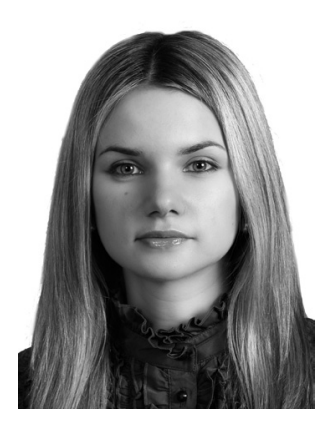

Юлия Геннадьевна Тищенко - ассистент кафедры «Гуманитарные и социальные науки» Шахтинского института (филиала) Южно-Российского государственного технического университета (Новочеркасского политехнического института).

Yulia Gennadievna Tishchenko - assistant lecturer at the «Humanities and Social Sciences» department of South-Russian State Technical University (Novocherkassk Polytechnic Institute) Shakhtinsky Institute (branch).

346500, г. Шахты, пл. Ленина, 1

1 Lenina sq., 346500, Shakhty, Rostov reg., Russia

Тел.: +7 (928) 766-99-96; e-mail: Yuliatisss@yandex.ru 